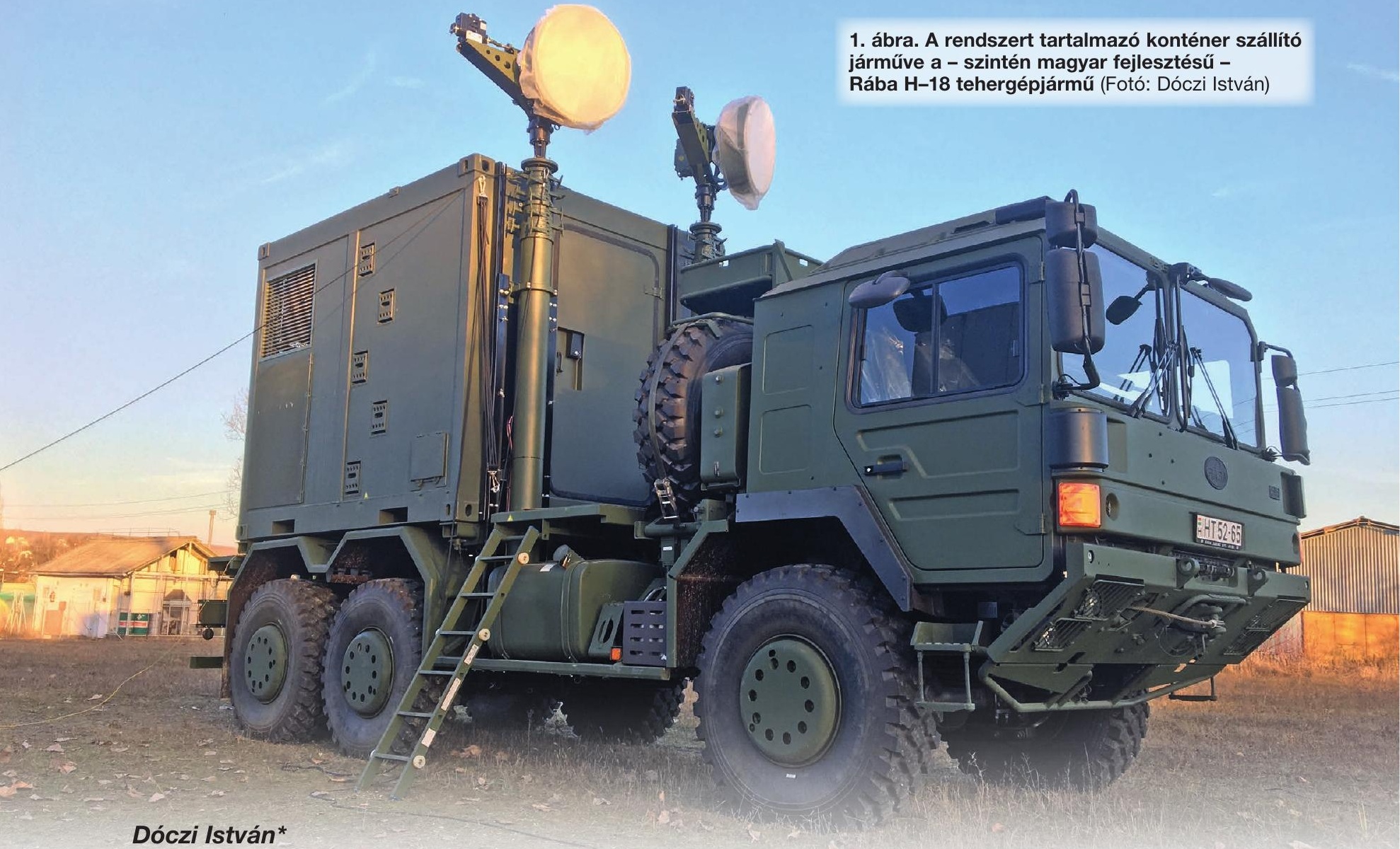

\title{
Hazai modernizáció a Magyar Honvédség tábori mikrohullámú rendszerében
}

A Magyar Honvédség a vezetés és irányítás híradó, informatikai és információvédelmi támogatása érdekében híradó, informatikai és információvédelmi rendszert üzemeltet, amely az ország különböző pontjain található stacioner és tábori állomásokból épül fel. Ez a hálózat a honi védelmi feladatok, és a szövetséges műveletek támogatására egyaránt alkalmas.

A XXI. század harcászati kihívásainak megfelelően a gyors és állandó hang- és nagy kapacitású adatkapcsolatok fenntartása stratégiai szempontból elengedhetetlen részét képezik a haderőnek, ezért 2016-ban megszületett egy digitális mikrohullámú mobil átjátszóállomás fejlesztésének gondolata, amelynek gyakorlati megvalósítását

ÖSSZEFOGLALÁS: A tanulmány célja a digitális, mikrohullámú átjátszóállomás prototípusának megvalósitásáról szóló tudósitás publikálása. Ez az eszköz szélsőséges körülmények között is képes átvenni - akár huzamosabb ideig is - egy megrongálódott vagy meghibásodott rádióállomás szerepét, vagy csomópontot alkotva kiterjeszteni a már meglévő hálózatot. A fejlesztés során számos komplex feladattal és megoldandó problémával szembesült a kivitelező, hiszen az eszköznek meg kellett felelnie a müszaki, katonai alkalmazási és harcászati követelményeknek is.

KULCSSZAVAK: RR-1/G, digitális mikrohullámú mobil átjátszóállomás, mikrohullámú átvitel, HM Armcom Zrt., rádiórelé hosszas szakmai előkészítő munkát követően a távközlésés híradástechnikában jártas HM ArmCom Zrt. nyerte el. [1]

\section{HADTÖRTÉNETI ELŐZMÉNYEK}

A mikrohullámú földfelszíni rendszerek térhódítása az 1940-es évek végén, az '50-es évek közepén vette kezdetét, amikor a mikrohullámú erősítéstechnika II. világháború alatt kifejlesztett eszköztárának polgári alkalmazására lehetőség nyílt. Az első európai digitális rádiórelé-rendszereket a '60-as évek elején alkalmazták. A kezdeti - nemzeti sajátosságokra szabott - digitális rendszereket a széles

ABSTRACT: The purpose of this short study is to report on the implementation of a prototype of a digital microwave repeater station. This device can take over the role of a damaged or malfunctioning radio station, even in extreme conditions, or extend the existing network as a node. During the development, the contractor faced a number of complex tasks and problems to be solved, as the device had to meet the military - application - tactical - requirements as well.

KEY WORDS: RR-1/G, digital microwave mobile repeater station, microwave transmission, MoD Armcom Corp., radio relay

Informatikus, HM ArmCom Zrt., Termelési Osztály. ORCID: 0000-0002-3587-9057 


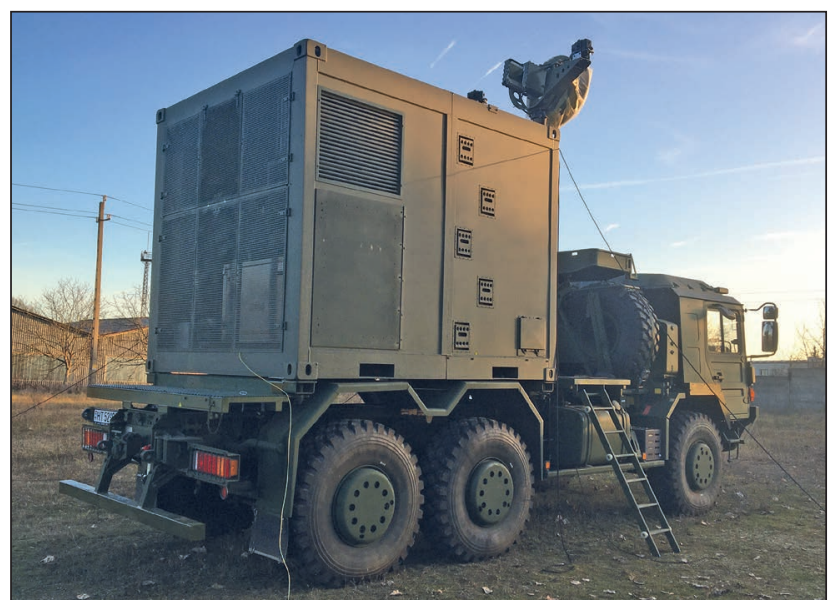

2. ábra. Az RR-1/G rádióreléállomás-konténer hátsó-oldalsó nézete (Fotó: Dóczi István)

körű nemzetközi szabványosítás, a kompatibilitásra való törekvés következtében a '60-as évek végén, a '70-es évek elején felváltották a $\mathrm{PCM}^{1}$-rendszerek újabb és újabb technológiai generációival. A digitális és az analóg technika közötti verseny véglegesen a '80-as évek elején-közepén dőlt el a digitális rendszerek javára. A technológiailag legfejlettebb országok már a '80-as évek végétől, a többiek pedig az 1990-es évek közepétől új, analóg mikrohullámú rádiórelé rendszereket már nem telepítettek. [2] [3]

\section{TeRVEZÉS ÉS KIVITELEZÉS}

A tervezőgárda már a kezdeti fázisban számos komplex feladattal és megoldandó problémával szembesült, amelyek alapos tervezési munkálatokat igényeltek, hogy az eszközkészlet megfeleljen a pályázati kírásban meghatározott műszaki, katonai alkalmazási és harcászati követelményeknek. Mind a gépészeti, mind az energetikai kivitelezések nagy körültekintéssel zajlottak, amelynek során elengedhetetlen volt a folyamatos konzultáció a belső és külső szakemberek között. [4] A magas színvonalú szakértelemnek köszönhetően egy olyan termék jött létre 2019-ben, amely a Magyar Honvédség elvárásainak megfelelően is alkalmazható, akár hazai, akár nemzetközi környezetben. [6]

A koncepció alapján két olyan terepjáró képességekkel rendelkező tehergépjármű alvázára szerelt, szabványos ISO 10 lábas konténerben elhelyezkedő digitális, mikrohullámú átjátszóállomás prototípusának megteremtése volt a cél, amely bármilyen körülmények között képes - akár huzamosabb ideig is - egy esetlegesen megrongálódott vagy meghibásodott állomás szerepének átvételére, vagy csomópontot alkotva, a már meglévő hálózat kiterjesztésére.

$\mathrm{Az}$ állomás tárolási hőmérséklet-tartománya: $-35^{\circ} \mathrm{C}$-tól $+70^{\circ} \mathrm{C}$-ig, míg üzemeltetési környezeti hőmérséklet-tartománya: $-25^{\circ} \mathrm{C}$-tól $+50^{\circ} \mathrm{C}$-ig terjed.

A rendszer egy speciális, a székesfehérvári székhelyü VT-Rendszertechnika Kft. szakembereivel közösen kialakított, 10 lábas konténerben kapott helyet. Az egyedi tároló eszközt egy Rába $\mathrm{H}-18$-as tehergépjármű konténerszállító rakfelületén helyezték el. A tehergépjármű kiválasztásánál fontos szerepet kapott a teherbírás és a terepjárási képesség, így esett a választás a $\mathrm{H}-18$-as bázisjárműre. A mechanikai kialakítás során figyelembe kellett venni a súlyeloszlást, a tereptulajdonságoknak történő megfelelést, az informatikai eszközök mechanikai védelmének kialakítását, és nem utolsó sorban, az ergonómiát. Az energetikai kivi-

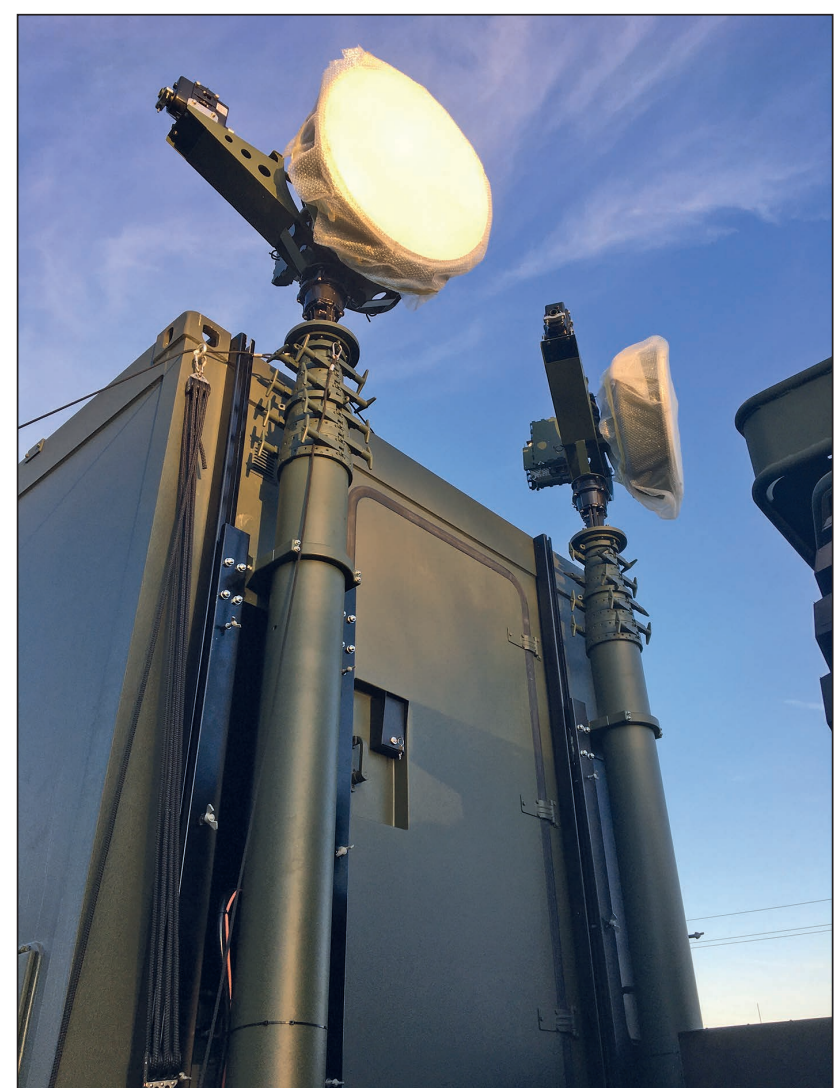

3. ábra. A mikrohullámú rádiórelék antennái az árbócokra rögzítve (Fotó: Dóczi István)

telezés során elvárás volt, hogy a felépítményen elhelyezkedő csökkentett zajkibocsátású aggregátor a helyi eszközök kiszolgálásán túl, képes legyen áttáplálni akár egy másik állomást is. Fontos tényező volt, hogy a járműfelépítményen elhelyezett, automatikus kitolású, megerősített antennaárbócok képesek legyenek elviselni fokozott szélterhelést is. Összességében a konténer kialakítása során előzetesen számos olyan tényezőt kellett szem előtt tartani a fejlesztőmérnököknek, amelyek alapjaiban határozták meg a további lépéseket.

A munkatérre és gépészeti térre felosztott konténerben egy csendes, dízelüzemű, $18 \mathrm{~kW}$ elektromos teljesítmény leadására képes aggregátor kapott helyet, amely szélsőséges körülmények között, hosszú távon is alkalmas stabil áramellátás biztosítására a munkatérben elhelyezett berendezések és kapcsolódó informatikai eszközök számára.

A gépészeti térben található a munkatér hűtését biztosító klímaberendezés kültéri egysége, valamint a szükséges szerszámok és egyéb kiegészítő kellékanyagok is. A könynyű szervizelés érdekében a géptér külön helyiséget képez a konténeren belül, minden tekintetben elválasztva a munkatértöl.

A munkatér hermetikus ajtón keresztül, létra segítségével közelíthető meg. A kiszolgáló személyzet megfelelő munkakörülményeit egy telepített munkaasztal, klímaberendezés és fütőberendezés biztosítja, míg védelmükről automata tűzoltóberendezés, álcafény, $\mathrm{ABV}^{2}$-szűrővel kombinált légtechnikai berendezés gondoskodik. A munkatérben két rackszerkényben található az eszközkészlet „lelke”. A berendezés energetikai ellátását az energetikai rackszekrény, míg a kommunikációs eszközök elhelyezését az informatikai rackszekrény biztosítja. Az energetikai szekrénybe telepítették a komplexum tápellátásért (külső, aggregá- 


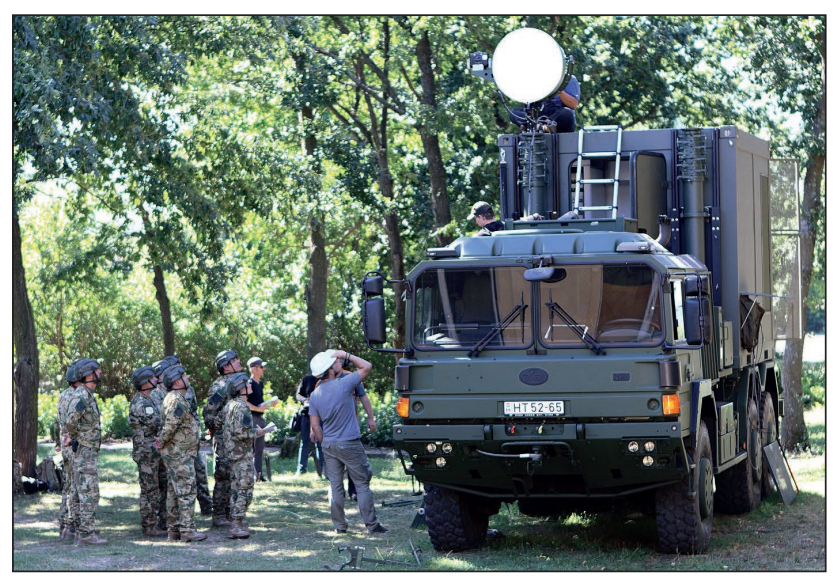

4. ábra. A HM ArmCom Zrt. mérnökei az antennák helyes rögzítésének módját demonstrálják a kezelőállománynak (Fotó: Révész Csaba)

toros vagy akkumulátoros) felelős kapcsolókat, megszakítókat és konvertereket, innen vezérelhető az aggregátor is, amelynek üzemanyagszintje folyamatosan figyelemmel kísérhető egy üzemanyagszint-visszajelző műszer segítségével.

Az informatikai szekrényben található tűzfal, router és a 2 darab switch a folyamatos és biztonságos adat- és hangkapcsolatokért felel, amelyek konfigurálásában az Enterprise Group az innovatív informatikai és infokommunikációs szolgáltatások és megoldások egyik vezető hazai rendszerintegrátorának munkatársai közreműködtek. Itt kaptak helyet a Totaltel Távközléstechnikai Kft. ${ }^{3}$ által biztosított nagy sebességű mikrohullámú berendezések belső egységei is, valamint a konténer oldalához rögzített árbócok távvezérlő egységei. A rendszer folyamatos tápellátásáról a szekrény alsó részén elhelyezett szünetmentes tápegység gondoskodik, amely a betáplálási oldalon lévő feszültségkiesés esetén képes az állomás több órán ke- resztül történő folyamatos üzemének biztosítására. A könynyű csatlakoztathatóság érekében a konténer két oldalán két panelt helyeztek el, amelyek egyike a különböző hálózati tápfeszültséggel történő betápláláshoz szükséges csatlakozókat tartalmazza, míg a másik panel a kültér felé történő optoelektronikai kapcsolatokért, valamint a mikrohullámú relé külső egységével történő összeköttetésért felel.

A TDR-M-V4-54 tábori mikrohullámú rádióberendezés gyorsan telepíthető, fix összeköttetés létesítésére szolgál, amely képes Ethernet technológiát alkalmazó hálózati elemek közötti transzparens adatátvitelre, valamint az E1 interfészek közötti jelátvitelre. A berendezések a 4400-5000 $\mathrm{MHz}$ frekvenciasávban működnek, a teljes sávot átfogják, a működési frekvencia $125 \mathrm{kHz}$-es lépésközzel állítható. A folytonos kétirányú kommunikációt a frekvenciaosztású duplex módtól (FDD) ${ }^{5}$ eltérően időosztású duplex módban (TDD) ${ }^{6}$ valósítja meg, adásra és vételre ugyanazt a frekvenciát használva, választhatóan 14 vagy $28 \mathrm{MHz}$ csatorna sávszélességgel. A berendezés többféle modulációs módban, 4-8-16-32-64-128 állapotú átvitellel használható, átviteli sebessége a modulációs módtól függően 17-26-35-4352-61 Mbit/s (28 MHz sávszélesség esetén), ami a TDDfunkciónak köszönhetően az alkalmazás során duplázódik.

A berendezés RF-jellemzői (csatornafrekvencia, adóteljesítmény, automatikus adószint-szabályozású /ATPC ${ }^{7} /-$ működés), valamint működési módja (moduláció, E1 interfészek száma, Ethernet-sebességek beállítása) a berendezéshez csatlakoztatott személyi számítógép segítségével szoftveresen konfigurálható.

A tábori mikrohullámú berendezések segítségével adatátviteli vagy $\mathrm{E} 1$ távközlési forgalom ágaztatható le a stacioner hálózat valamely állomásáról. A stacioner hálózatról leágazó tábori mikrohullámú összeköttetések berendezései beköthetők a stacioner hálózat hálózatfelügyeleti központjába és az MXMSS ${ }^{8}$ távfelügyeleti rendszer központi gépén felügyelhetők.

A berendezések osztott kivitelűek, az antennával egybeépíthető kültéri egységből (ODU) és beltéri egységből

1. táblázat. Néhány fontosabb rádiórelé föbb müszaki paramétereinek összehasonlítása

(A szerző szerkesztése gyári katalógusadatok alapján)

\begin{tabular}{|l|c|c|c|}
\hline Gyártó & Totaltel & Transbit & Kongsberg \\
\hline Származási hely & Magyarország & Lengyelország & Norvégia \\
\hline Típus & TDR-M-V4 & R-460S & RL542A \\
\hline Sáv [GHz] & $4,4-5$ & $4,4-5$ & $4,4-5$ \\
\hline Max. sávszélesség [MHz] & 56 & 28 & $\mathrm{NA}$ \\
\hline Max. kapacitás (64QAM) ${ }^{10}$ [Mbit/s] & 102 & $(\max .100)$ & 100 \\
\hline Ptx (64QAM) [dBm] & 24 & $($ max. 34$)$ & 29 \\
\hline Vrx (64QAM) [dBm] & -65 & $\mathrm{NA}$ & -76 \\
\hline Technológia & TDD v. FDD & $\mathrm{FDD}$ & $\mathrm{FDD}(75 \mathrm{MHz})$ \\
\hline Üzemi feszültség & $23-60 \mathrm{~V} \mathrm{v.} 230 \mathrm{~V}$ & $22-54 \mathrm{~V} \mathrm{v.} 230 \mathrm{~V}$ & $19 / 60 \mathrm{~V}$ \\
\hline Múködési hömérséklet-tartomány & $-40-+50{ }^{\circ} \mathrm{C}$ & $-30-+50{ }^{\circ} \mathrm{C}$ & $-40-+60{ }^{\circ} \mathrm{C}$ \\
\hline Frekvenciastabilitás & $\pm 5 \mathrm{ppm}^{11}$ & $\pm 5 \mathrm{ppm}$ & $\pm 5 \mathrm{ppm}$ \\
\hline Moduláció (QAM) & $4,8,16,32,64,128$ & $16,64,128$ & $4,16,64$ \\
\hline Beltéri egység tömege (kg) & 8 & $\mathrm{~kb} .12$ & - \\
\hline Kültéri egység tömege (kg) & 5 & $\mathrm{~kb} .4$ & 14 \\
\hline
\end{tabular}




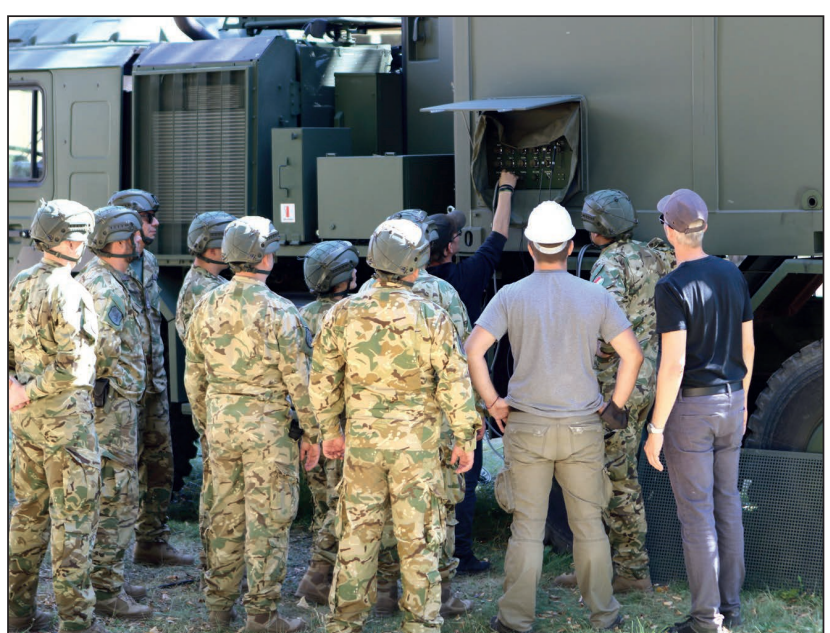

5. A konténer oldalfalán található informatikai csatlakozópanel részeinek bemutatása (Fotó: Révész Csaba)

$\left(\right.$ IDU $\left.^{9}\right)$ állnak, amelyeket maximálisan 300 m hosszúságú koaxiális kábel köt össze. Az ODU-hoz csatlakozó standard antenna 0,6 $\mathrm{m}$ átmérőjű parabolaantenna. $\mathrm{A}$ berendezések 30-60 V DC egyenáramú táplálásúak.

A TDR-M-V4-5 tábori mikrohullámú rádióberendezések robusztus mechanikai kivitele biztosítja a szállíthatóság és a könnyen kezelhetőség feltételeit. A berendezés kültéri eszközei lehetővé teszik az összeköttetés működését $-40{ }^{\circ} \mathrm{C}$ és $+55^{\circ} \mathrm{C}$ közötti hőfoktartományban, 100\%-os páratartalom mellett. A beltéri egység környezeti feltételei: $-10^{\circ} \mathrm{C}$ és $+45^{\circ} \mathrm{C}$ közötti hőfoktartomány, és max. $80 \%$-os páratartalom.

A HM ArmCom Zrt. 2018-ban előzetes piackutatást végzett a kereskedelemben fellelhető ismertebb gyártók rádióreléivel kapcsolatban. A kutatás eredményeit a $\mathrm{MH}$ illetékeseivel egyeztetve, több értékelési szempont figyelembevételével három gyártó termékére szűkítették a résztvevők, amelyek a norvég Kongsberg, a lengyel Transbit valamint a fentiekben ismertetett magyar fejlesztésű Totaltel relé. Az eszközök fontosabb műszaki paramétereinek összehasonlítását az 1. táblázat tartalmazza.

A táblázatból kiolvasható, hogy az összehasonlítási szempontrendszer eredményeiben számos érdemi különbség nem mutatkozott a hazai és a külföldi fejlesztésű relék között. Sávszélességben, hatékonyságban, sebességben és stabilitásban közel azonos eredményekkel szolgálnak az eszközök. A hazai védelmiipari fejlesztés szempontrendszerének figyelembevételével, a támasztott igények alapjánm, a Totaltel által fejlesztett relé bizonyult a legalkalmasabbnak.

Ugyancsak a rendszer részét képezi állomásonként $5 \mathrm{db}$ megerősített kivitelű Dell Latitude 5424 Rugged notebook és Aqeri 96400 IP-telefon is, amelyek a kiszolgáló személyzet munkáját segítik a folyamatos kapcsolattartásban. Az informatikai rendszer teljes funkcionalitásához szükséges külső optikai és rézkábelek a konténer és a vezetőfülke között, zárható fémszekrényekben kaptak helyet.

\section{Összegzés}

A RR-1/G (P) komplexum rendszerként történő mobilizálhatósága, a mikrohullámú hálózat üzemeltethetőségének és kihasználásának tekintetében olyan hozzáadott stratégiai értéket képvisel a honvédelemben, amely méltó helyet kell, hogy kapjon a fejlesztési irányvonalak között. Az esz-

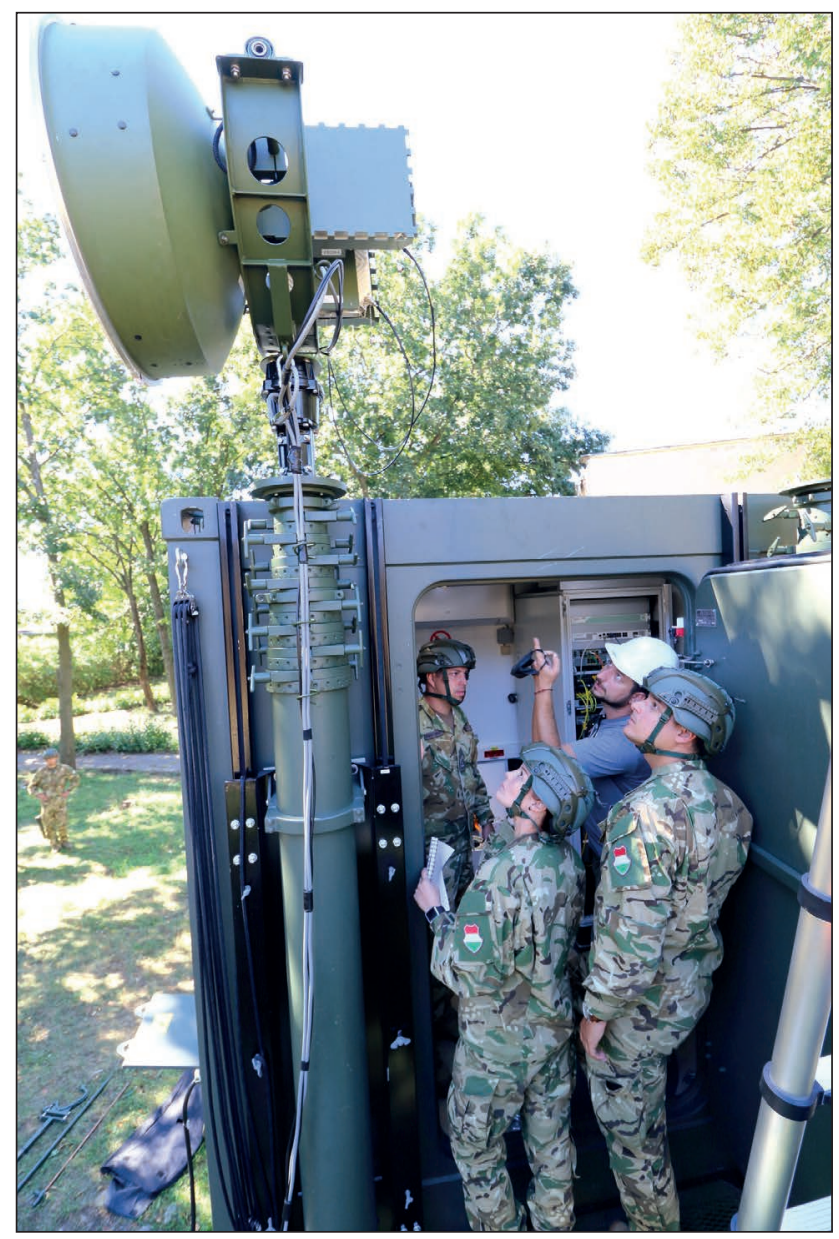

6. ábra. Grócz Olivér fejlesztő-tervező gépészmérnök az árbócok kitolását és az antennaforgatók múködését ismerteti (Fotó: Révész Csaba)

közrendszer átadását követően az oktatások és csapatpróbák során számos pozitív visszajelzés érkezett az alakulatok részéről, amelyek nagyban segítették a tervezőgárdát a termék továbbfejlesztésében. [6]

A Zrínyi Honvédelmi és Haderőfejlesztési Programban meghatározott alapelvekben szereplő korszerű eszközökkel felszerelt, modern technológiákat alkalmazó és nemzetközi viszonylatban is használható eszközök beszerzése és gyártása az elmúlt évek során fokozatosan erősödő szerepet kapott Magyarországon. A modernizáció egyik fontos állomását jelenti a fentiekben bemutatott RR-1/G (P) komplexum sikeres megtervezése és gyártása. Mind a gépészeti, mind az energetikai kivitelezések nagy körültekintéssel zajlottak, bevonva a VT-Rendszertechnika Kft. és a Totaltel Távközléstechnikai Kft. szakembereit is. A stacioner hálózatról leágazó tábori mikrohullámú összeköttetések berendezései beköthetők a stacioner hálózat hálózatfelügyeleti központjába is, ily módon a távfelügyeleti rendszer által felügyelhetők. Az így elért eredményben külön üdvözlendő, hogy a fejlesztés csaknem teljes egésze a hazai mérnökök munkájának eredménye.

Úgy a megrendelő, mint a tervező és kivitelező csapat is reméli, hogy a két prototípus megalkotása csak a kezdeti lépés volt annak irányában, hogy az olyan - közel 30 éves tapasztalattal rendelkező - hadiipari vállalatok, mint a HM ArmCom Zrt., valamint a HM Currus Zrt. újra lehetőséget és aktív szerepet kapjanak a magyar hadiipar fejlesztésében. 


\section{HivATKOZOTT IRODALOM}

[1] Révész Béla, „Az elgondolástól a beszerelésig” Honvédelem.hu 2020. 10. 7. https://honvedelem.hu/ hirek/az-elgondolastol-a-beszerelesig.html (Letöltve: 2021.4.22.);

[2] Fekete Károly, A Magyar Honvédség állandó telepítésü kommunikációs rendszere továbbfejlesztésének technikai lehetőségei PhD értekezés Bp.: ZMNE 2003. https://nkerepo.uni-nke.hu/xmlui/bitstream/ handle/123456789/11952/Teljes\%20sz\%F6veg!. pdf?sequence=1 (Letöltve: 2021.4.20.);

[3] Somogyi András, Kántor Csaba, „Mikrohullámú rádiórelé rendszerek: jelen és jövő" Híradástechnika, 41. évf., 7-8. szám (1990) https://www. hiradastechnika.hu/data/upload/file/1990/0708/1990_0708_02.PDF (Letöltve: 2021.4.15.);

[4] Pándi Balázs, $A$ tábori hírrendszer vizsgálata az alkalmazhatóság hatékonyságának növelése érdekében PhD értekezés Budapest: ZMNR KMDI 2009. https:// nkerepo.uni-nke.hu/xmlui/bitstream/ handle/123456789/12161/ertekezes.pdf?sequence $=1$ (Letöltve: 2021.4.20.);

[5] Gyimóthy Levente, „Élesben is bevetették a magyar fejlesztésű rádiórelét Székesfehérváron" Honvédelem. hu 2020. 9. 9. https://honvedelem.hu/hirek/elesben-is- bevetettek-a-magyar-fejlesztesu-radioreletszekesfehervaron.html (Letöltve: 2021.4.22.);

[6] Gyimóthy Levente, „Az új magyar rádiórelé használatát gyakorolták" Honvédelem.hu 2020. 9. 17. https:// honvedelem.hu/hirek/az-uj-magyar-radiorelehasznalatat-gyakoroltak.html (Letöltve: 2021.4.22).

JEGYZETEK
1 PCM - Pulse Code Modulation (Impulzuskód moduláció).
A beszédátvitelben az analóg jelek digitális átviteli közegen történő
továbbítására használják.
2 ABV - atom, biológiai, vegyi.
3 http://www.totaltel.hu/.
4 TDR - Totaltel Flexibilis Digitális Rádióberendezés család tagjai
$2 \times 2$ Mbit/s-tól $2 \times(34+2)$ Mbit/s-ig terjedő sebességú digitális jelek
továbbítására, vagy Ethernet hídként lokális hálózatok
összekapcsolására szolgálnak.
5 FDD - Frequency Division Duplexing (Frekvenciaosztásos duplex
átvitel).
6 TDD - Time Division Duplexing (Időosztásos duplex átvitel).
7 ATPC - Automatic Transmit Power Control (Automatikus
adóteljesítmény-szabályozás).
8 MXMSS - Mobile PCI Express Module Signal Service.
9 ODU - Outdoor Unit, IDU - Indoor Unit (kültéri-beltéri egység).
10 QAM - Quadrature Amplitude Modulation (kvadratúra
amplitúdómoduláció).
11 ppm - Parts per million (Az egész rész milliomod része).

\section{JEGYZETEK} továbbítására használiák. továbbítására vagy Ethernet hídként lokális hálózatok

összekapcsolására szolgálnak.

átvitel).

6 TDD - Time Division Duplexing (Időosztásos duplex átvitel).

(Automatikus ny-szabályozás).

9 ODU - Outdoor Unit, IDU - Indoor Unit (kültéri-beltéri egység).

amplitúdómoduláció).

\section{Elhunyt prof. dr. Halász László ezredes}

$$
\text { (1941-2021) }
$$

Életének 81. évében elhunyt Halász László nyugállományú ezredes, az MTA doktora, a Haditechnika folyóirat rendszeres szerzője és lektora. Halász professzor úr az elmúlt három évtizedben számos tanulmányt publikált lapunk hasábjain. Munkáinak fókuszában elsősorban a vegyivédelem állt. A Haditechnikában többek között a mérgező harcanyagok legkorszerübb laboratóriumi kimutatási és meghatározási módszereiről (1992/4.), a Haditechnikai Intézet által fejlesztett vegyi távfelderítő berendezésekről (1993/1.), a vegyivé-



1967-től a HM Haditechnikai Intézet tudományos kutatójaként. 1983-ban a tudományos osztály vezetőjévé nevezték ki, ebből a beosztásából vonult nyugállományba.

A felsőoktatási munkával 1973-ban jegyezte el magát, 1998-tól a Zrínyi Miklós Nemzetvédelmi Egyetem oktatója volt. 2002-ben részt vett a Katonai Műszaki Doktori Iskola alapításában, 2003-tól négy esztendőn keresztül vezetőként irányította annak munkáját. 2004 és 2005 között a ZMNE Vegyivédelmi Tanszék tanszékvezetője volt. A katasztrófavédelmi delem hazai történetének kutatómunkájáról (1996/3.), a vegyi- és biológiai védelem Egyesült Államokban folytatott fejlesztési irányairól (2000/4.), valamint a klímaváltozás kihívására adott válaszként a harcjárművek ABVRvédelmének javításáról (2013/3.) közölt cikkeket szerzőként, illetve társszerzőként.

Halász László 1941. április 30-án Budapesten született. Felsőfokú tanulmányait a Budapesti Műszaki Egyetem vegyészmérnöki karán végezte, majd ugyanott környezetvédelmi szakmérnöki diplomát szerzett. Műszaki doktori értekezését 1968-ban védte meg, 1976-ban a kémia tudomány kandidátusává nevezték ki, 1991-ben a kémia és a hadtudomány doktorává avatták. 1964-től dolgozott a Magyar Néphadseregben, előbb a Vegyivédelmi Anyagátvételi Osztály átvevő főtisztjeként, majd menedzser szak megindulásával kidolgozta annak szakalapozó tantárgyait. 2011-től viselte a professzor emeritus címet. 1985-ben választott tagja lett a Magyar Tudományos Akadémia Kémiai Tudományok Osztálya, Analitikai Kémiai, Kolloidkémiai és Műanyagfizikai Munkabizottságainak. Számos magyar és nemzetközi elismerésben részesült. 2000-ben elnyerte a Széchenyi Professzori Ösztöndíjat.

Dr. Halász László Professzor Úr a vegyivédelmi szakterület doyenjeként generációkat oktatott a katonai környezetbiztonságra. Cikkeivel, tanulmányaival a Haditechnika olvasótáborának is minden alkalommal a korának legkorszerủbb ismereteit nyújtotta át.

Emlékét őrzik egykori kollégái, tanítványai, és szerkesztőségünk munkatársai. 